\title{
Students' Awareness towards Climate Change: A Study of Climate Change Effects on Human Health in Nepal
}

\author{
${ }^{1}$ Bhawana Gautam \\ ${ }^{2}$ Punam Kumari Mandal \\ ${ }^{3}$ Namita Yangden \\ ${ }^{1}$ Department of Cardiology, Neuro Cardio \& Multispecialty Hospital, Biratnagar, Nepal \\ ${ }^{2,3}$ Department of Community Health Nursing, Biratnagar Nursing Campus, Nepal
}

Article History: Submitted 10 February 2021; Reviewed 21 April 2021; Accepted 25 April 2021 Corresponding Author: Punam Kumari Mandal, Email: poomandal@gmail.com DOI: https://doi.org/10.3126/paj.v4i0.37006

Copyright 2021 @ A Author/s and Centre for Research and Innovation. This work is licensed under a Creative Commons Attribution 4.0 International (CC BY 4.0) License.
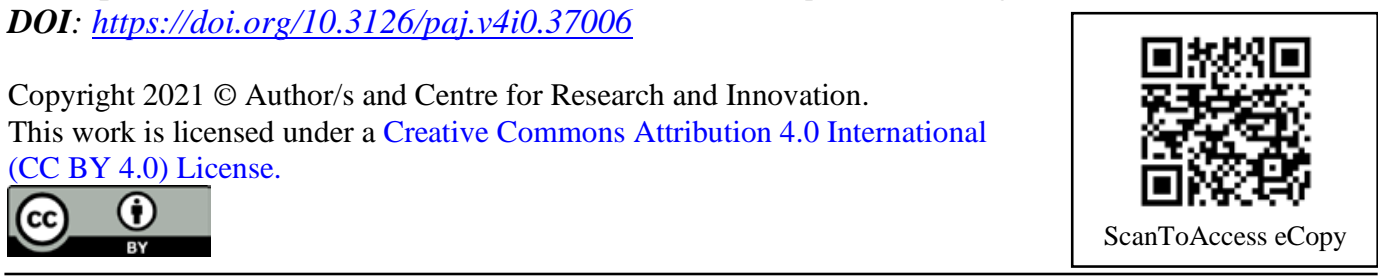

\begin{abstract}
Climate change and its impact on human health and awareness constitute a set of complex and serious consequences to be tackled by an individual country. It is not merely an environmental issue, but it is also a threat that goes beyond the national borders. The purpose of this study is to assess the awareness on effect of climate change on human health among the secondary level students of Biratnagar. The research design was descriptive cross-sectional and data was collected from 110 samples through the census method using the semi-structured self-administered questionnaire. Among the respondents, $84.5 \%$ knew that climate change can be prevented. Moreover, 50.9\% perceived that climate change is an unbreakable process; $77.3 \%$ of them perceived climate change is the cause of new disease; and $81.8 \%$ of them are concerned about preventing the effects of climate change on human health. Among the respondents, 10\% had adequate awareness. The study concluded that half of the secondary level students have inadequate level of awareness on effects of climate change on human health in Biratnagar. It is recommended that awareness should be increased by involving them in the project work activities and reinforcing the component of curriculum.
\end{abstract}

KEYWORDS: Awareness, climate change, health effect, climate change education

\section{INTRODUCTION}

Climate change can exacerbate existing health threats or create new public health challenges through a variety of pathways. Humans have done much development since the industrial age; however, these improvements come along at a cost. Climate impact such as an increase in temperature, precipitation extremes, extreme weather events and 
rise in sea level impacts of change in exposure i.e. extreme heat, poor air, food and water quality and change in infectious agent which has negative impact in human health (United States Environmental Protection Agency, 2017).

Climate change affects the social and environmental determinants of health such as clean air, safe drinking water, sufficient food and secure shelter. By the year 20302050, climate change is expected to cause approximately 250,000 additional deaths per year from malnutrition, malaria, diarrhoea and heat stress. By the late twenty-first century, climate change is likely to increase frequency and intensity of drought at global scale. The increase of temperature and variable precipitation decrease food production and increase the prevalence of malnutrition and undernutrition (World Health Organization, 2018). The climate change and its rapid emergence in the past decades together with health inequality and infectious diseases is a major challenge to public health in Nepal. It is likely to influence mortality and morbidity due to vector borne and zoonotic diseases, water borne diseases, flooding and accidents/injuries, cardiovascular diseases, and malnutrition which is increasing in Nepal every day (Dhital et al, 2016). A study done in Tanzania shows that students at the secondary school have some knowledge and awareness of climate change, but significant gaps in knowledge exist (Carr et al., 2015). Thus, awareness related to climate change impact on health is important to have a better adaptive capacity for the teenagers.

Similarly, Rahman et al. (2018) conducted a survey among the young generation in Dhaka. The results indicated that young generations are aware of perceived physical impact due to climate change. However, majority of the young citizens are unaware of the impact of perceived psychological issues affecting overall individual behavior due to the effect of climate change. Another study showed that the level of awareness of secondary school students about climate change was moderate. The study concluded that orientation programs on climate change should be organized for the students frequently along with seminars and workshops for the subject teachers to enhance their experience in providing students with the appropriate problem-solving and decisions making skills on climate change (Bello, 2014). Likewise, a cross-sectional study among medical, public health and nursing students in universities in China showed only 58\% students correctly identified the causes of climate change, $88 \%$ respondents believed that climate change is bad for human health and $67 \%$ of respondents believed that climate change is controllable (Yang et al., 2018).

Education is an essential element of the global response to climate change. Climate change education helps young people comprehend and address the impact of global warming. Furthermore, it encourages changes in their attitudes and behavior and helps them adapt to the climate change related trends (Shaho et al., 2017). Climate change education has been incorporated in school curriculum from 2014 in Nepal in different subjects and teaches students about climate change (Ministry of Science, Technology and Environment, 2015).

Knowledge on climate change is perceived as a part of formal environmental education that helps in development of a sense of responsibility through the creation of informed awareness. Thus, such awareness is necessary to guide students' behavior towards concerted improving actions (Rahman et al., 2014). Different studies conducted shows students have moderate knowledge on climate change and its effect. Till date, most climate change researches are focused on environmental effects rather than health effects despite being clear that it endangers human health. As classroom is the most important unit of the educational system, climate change awareness and its impact on health play a significant role in shaping the pro-environment attitudes of the school students and may empower them combating its adverse effect on the region and the 
country. Since limited studies are conducted in this topic regarding country context so it is important to assess the awareness on effect of climate change on health. The objective of this study is to assess awareness on effect of climate change on health among secondary level students in Biratnagar.

\section{MATERIALS AND METHODS}

The descriptive cross-sectional study was conducted to assess the awareness on effect of climate change on health among secondary level students studying in class IX and X of Jaycee Bal Sadan Secondary School in Biratnagar-13. Biratnagar is a metropolitan city, which consists of 19 wards and 105 private schools. There are five private schools in Biratnagar - 13 and Jaycee Bal Sadan Secondary School is one of them which was established in 2030 B.S., consisting around 950 students. The location of research was purposively selected as secondary level students that would undoubtedly be the primary route to educate the population towards climate awareness and its effect on health. Also, it is believed that a successful dissemination of knowledge at the high school level is critical to ensure lifelong pro-environment behavior among future citizen of the country. Besides, limited studies on awareness on effect of climate change on health have been conducted in private schools in our country context.

For data collection, the self-administered semi structured questionnaire was developed in English version on the basis of objectives of the study. Research instruments contained two distinct parts: Part I: Socio-demographic information and Part II: Awareness on effect of climate change on health (includes questions related to knowledge and perception on climate change, cause of climate change, effect of climate change, effect of climate change on health and its preventive measures). Content validity of the instrument was maintained by extensive literature review and consulting with the subject experts. Pretest was done on $10 \%$ of the sample size. According to the findings of the pretest, the questionnaire modification was done in the knowledge and perception part. The questionnaire was finalized after consulting with the expert in English. The knowledge section included 15 semi-structured questions with multiple choice, multiple responses and dichotomous (Yes/No) questions and the perception section included 10 semi-structured dichotomous questions. Each question related to knowledge and perception carried one mark but in case of multiple responses each correct response consists of one mark. The total score was then converted into percentage and was interpreted as follows: above $75 \%$ adequate awareness, (55-75) \% moderate awareness and below $55 \%$ inadequate awareness.

Data was collected by the census method from a total 110 students on 2075/02/07. Prior to the data collection approval was taken from the Research Management Committee of Biratnagar Nursing Campus, Tribhuvan University, Institute of Medicine, Biratnagar. The approval letter was taken from Principal of the concerned schools for conducting the study. The written informed consent was also taken from each respondent after explaining the purpose of the study. Privacy, confidentiality of information of all the respondents was maintained. The respondent was explained about the nature and purpose of the study after collecting them in a class. After that, an instruction for completing the questionnaire was specified before the distribution of questionnaires. The informed consent was taken before administering the questionnaire to them. Approximately, 25-30 minutes were taken for each individual. During the time of data collection, monitoring was done to prevent contamination of the data among the participants. The collected data were checked for its completeness. Only the researchers were involved in data collection. 
All the data were kept in order for editing and coding. Data processing was done by using the Statistical Package for the Social Sciences (SPSS) version 16.0. Descriptive analysis such as frequency, percentage, mean and standard deviation were used.

The study was conducted in one private school in Biratnagar-13 and the sample was non-randomized, which limits the samples generalizability.

\section{RESULTS}

In this study, the mean age and standard deviation of the respondents was 14.66 \pm 0.84 with the equal male female proportion i.e. $50 \%$ where $51 \%$ were from Madheshi ethnic group and $95.5 \%$ of them were from the Hindu religion. Likewise, $43.6 \%$ of respondent's father and $42.7 \%$ of respondent's mother completed the secondary level education. Regarding their occupation, $41.8 \%$ were private employee and $77.2 \%$ of respondent's mothers were homemaker. The most popular source of information was television $(77.3 \%)$.

Among respondents, $27.3 \%$ answered the correct meaning of climate change and $73.6 \%$ stated increased temperature as the consequences of climate change. Afterwards, $54.6 \%$ respondents disagreed that the climate change cause cancer and more over $20 \%$ respondents do not know that the climate change cause the mental problem. Meanwhile, $84.5 \%$ respondents know that the climate change can be prevented. When asked about the perception of climate change, $50.9 \%$ respondents perceived that the climate change is an unbreakable process, $60 \%$ perceived that it is not too late to do anything about climate change and its effect on health, $77.3 \%$ of them stated climate change is the cause of new disease and $81.8 \%$ of them are concerned about preventing the effects of climate change on health. This study shows that $51.8 \%$ of respondents had inadequate awareness about the climate change and its effects on health.

Table 1

Knowledge of Climate Change $n=110$

\begin{tabular}{lcc}
\hline Response & Frequency(f) & Percentage (\%) \\
\hline Meaning of climate change & 38 & \\
$\quad$ Change in weather over months & 30 & 34.5 \\
$\quad$ Change in weather over decades & 29 & 27.3 \\
Change in weather over days & 13 & 26.4 \\
$\quad$ Change in weather over years & & 11.8 \\
Source of information* & 85 & \\
$\quad$ Television & 73 & 77.3 \\
Teachers & 65 & 66.4 \\
Internet & 59 & 59.1 \\
Textbook in school & 55 & 53.6 \\
Newspaper & 49 & 50.0 \\
$\quad$ Radio & 33 & 44.5 \\
Friends/family & 30 & 30.0 \\
$\quad$ Environmental worker & & 27.3 \\
Cause of climate change* & 85 & 77.3 \\
$\quad$ Industrialization & 76 & 69.1 \\
$\quad$ Deforestation & & \\
$\quad$ Release of greenhouse gases $\left(\mathrm{CO}_{2}\right.$, & 74 & 67.3 \\
methane, etc.) & & \\
\hline
\end{tabular}

Prithvi Academic Journal, Volume 4, May 2021 [pp. 18-26] 


\begin{tabular}{lll}
\hline Excess use of chemical fertilizer & 69 & 62.7 \\
Earthquake & 32 & 29.1 \\
Volcano & 21 & 19.1 \\
\hline
\end{tabular}

*Multiple response questions

Table 2

Knowledge on Effects and Consequences of Climate Change

\begin{tabular}{|c|c|c|}
\hline Response & Frequency(f) & Percentage(\%) \\
\hline \multicolumn{3}{|c|}{ Climate change affecting rain pattern } \\
\hline Yes & 101 & 91.8 \\
\hline No & 9 & 8.2 \\
\hline \multicolumn{3}{|c|}{ Climate change affecting wind pattern } \\
\hline Yes & 96 & 87.3 \\
\hline No & 14 & 12.7 \\
\hline \multicolumn{3}{|l|}{ Wind pattern $(n=96)$} \\
\hline Increasing & 85 & 88.54 \\
\hline Decreasing & 11 & 11.46 \\
\hline \multicolumn{3}{|c|}{ Consequences of climate change* } \\
\hline Increased temperature & 81 & 73.6 \\
\hline Flood & 74 & 67.3 \\
\hline Melting of snow & 71 & 64.5 \\
\hline Excessive rain & 68 & 61.8 \\
\hline Landslide & 52 & 47.3 \\
\hline Drought & 15 & 13.6 \\
\hline \multicolumn{3}{|c|}{ Observed impact of climate change* } \\
\hline Health effects & 79 & 71.8 \\
\hline Seasonal change & 79 & 71.8 \\
\hline Flood & 63 & 57.3 \\
\hline Irregularities in rainfall & 59 & 53.6 \\
\hline Landslide & 26 & 23.6 \\
\hline Strom & 26 & 23.6 \\
\hline Drought & 13 & 11.8 \\
\hline \multicolumn{3}{|c|}{ Extreme weather related issues due to } \\
\hline climate change* & 74 & 67.3 \\
\hline Heat waves & 69 & 62.7 \\
\hline Cold waves & 45 & 40.9 \\
\hline Flood & 24 & 21.8 \\
\hline Drought & & \\
\hline
\end{tabular}

Table 3

Knowledge on Effects of Climate Change on Health

\begin{tabular}{lcc}
\hline Response & Frequency (f) & Percentage (\%) \\
\hline $\begin{array}{l}\text { Water borne disease due to climate } \\
\text { change* }\end{array}$ & & \\
$\quad$ Diarrhoea & 82 & 74.5 \\
$\quad$ Skin disease & 69 & 62.7 \\
\hline
\end{tabular}

Prithvi Academic Journal, Volume 4, May 2021 [pp. 18-26] 


\begin{tabular}{lcc}
\hline $\begin{array}{l}\text { Typhoid } \\
\text { Nutritional deficiencies due to climate } \\
\text { change* }\end{array}$ & 59 & 53.6 \\
$\quad \begin{array}{l}\text { Decreased nutrient value in food } \\
\text { Marasmus }\end{array}$ & 57 & 51.8 \\
Kwashiorkor & 38 & 34.5 \\
$\quad$ Do not know & 21 & 19.1 \\
Vector borne disease related to climate & 36 & 32.7 \\
change* & & \\
$\quad$ Malaria & 98 & 89.1 \\
Dengue & 76 & 69.1 \\
Kalazar & 20 & 18.2 \\
Japanese encephalitis & 11 & 10 \\
Air pollution related problem due to & & \\
climate change* & & 70 \\
$\quad$ Asthma & 77 & 59.1 \\
Respiratory allergies & 65 & 16.4 \\
Bronchitis & 18 & 21.8 \\
Climate change cause cancer & & 54.5 \\
Yes & 24 & 23.6 \\
No & 60 & \\
Do not know & 26 & 44.5 \\
Climate change cause mental problem & & 35.5 \\
Yes & 49 & 20 \\
No & 39 & \\
Do not know & 22 & \\
\hline
\end{tabular}

*Multiple response questions

Table 4

Perception on Climate Change and its Effects

\begin{tabular}{|c|c|c|c|}
\hline Perception & $\begin{array}{l}\text { Yes } \\
\text { f (\%) }\end{array}$ & $\begin{array}{l}\text { No } \\
\text { f (\%) }\end{array}$ & $\begin{array}{l}\text { Don't Know } \\
\text { f (\%) }\end{array}$ \\
\hline Climate change is an unbreakable process & $56(50.9)$ & $36(32.7)$ & 18(16.4) \\
\hline $\begin{array}{l}\text { People are experiencing the effect of climate } \\
\text { change now }\end{array}$ & $92(83.60$ & 11(10) & $7(6.4)$ \\
\hline $\begin{array}{l}\text { Increase atmospheric carbon dioxide decrease } \\
\text { nutritional value of crops }\end{array}$ & $72(65.5)$ & $7(15.5)$ & 21(19.1) \\
\hline $\begin{array}{l}\text { It is already too late to do anything about } \\
\text { climate change and its effect on health }\end{array}$ & $36(32.7)$ & $66(60)$ & $8(7.3)$ \\
\hline Climate change is the cause of new diseases & 85(77.3) & 18(16.4) & $7(6.4)$ \\
\hline $\begin{array}{l}\text { Climate change is just a natural fluctuation of } \\
\text { earth's temperature }\end{array}$ & $63(57.3)$ & $32(29.1)$ & 15(13.6) \\
\hline $\begin{array}{l}\text { Excessive heat and cold is possibly increase by } \\
\text { climate change }\end{array}$ & $85(77.3)$ & 19(17.3) & $6(5.5)$ \\
\hline $\begin{array}{l}\text { Human activities are one and only the cause of } \\
\text { climate change }\end{array}$ & $67(60.9)$ & 33(30) & 10(9.1) \\
\hline $\begin{array}{l}\text { The rise of sea level is one climate change } \\
\text { impact }\end{array}$ & $95(86.4)$ & $7(6.4)$ & $8(7.3)$ \\
\hline
\end{tabular}


You are concerned about preventing the effect $\quad 90(81.8) \quad 14(12.7)$ of climate change on health

\section{DISCUSSION}

The findings of this study indicate that $27.3 \%$ of the respondents knew the correct meaning of climate change as change in weather over decades, which corresponds with the study conducted in Ghana where $37.2 \%$ of the respondent gave the scientific meaning of climate change (Barimah et al., 2015). The study reveals that the most important source of information among the respondent was television (77.3\%), followed by teacher, internet, textbook in school which is similar to the findings of the study conducted in Tanzania where the electronic media are more dominant source of information together with schools and traditional mass media such as television, newspaper, radio, etc. (Carr et al., 2015).

In term of the cause of climate change, majority of the respondents identified the human-made cause such as industrialization (77.3\%), deforestation (69.1\%), release of greenhouse gases (67.3\%), which is supported by the study conducted in two states in the western region of Nigeria where majority of the respondents ascribing main causes to pollution from heavy industries (73\%) and human activities (75\%) (Theora, 2014). The study conducted by Barimah et al. in Ghana where most of the respondents were aware of changing trends in atmospheric temperatures and rainfall patterns and another study conducted in Bangladesh also illustrates similar effects and consequences such as an increase in temperature, rainfall pattern, flood which is similar to the current study which shows $91.8 \%$ respondents said climate change affects rain pattern, and $73.6 \%$ said increased temperature (Kabir et al., 2016). Likewise, the results of a cross-sectional study conducted among medical, public health and nursing students in universities in China in 2017 among 1387 students sampled in five different regional universities in China showed only 58\% students correctly identified the causes of climate change, $88 \%$ respondents believed that climate change is bad for human health and $67 \%$ of respondents believed that climate change is controllable (Yang et al., 2018).

In term of preventive measure of climate change, $66.4 \%$ of the respondents believe in afforestation and $57.3 \%$ believe in environmental sanitation which is supported by the study conducted on Protecting Health from Climate Change: Preparedness of Medical Interns where decreasing the use and dependency on fossil fuels, more use of renewable sources of energy, decreasing air pollution, reforestation was stated as the preventive measures (Majra \& Acharya, 2009). This study illustrates that $50.9 \%$ of the respondents perceived that climate change is an unbreakable process, $86.4 \%$ of the respondents perceived raise at sea level as one of the impact of climate change which correlates with the findings of the study conducted in Indonesia where $59.25 \%$ of the respondents perceived that climate change is an unbreakable process and $73.43 \%$ of the respondents perceived one of the impact of climate change is raise at sea level (Sulistyawati et al., 2018).

The findings of the study conducted in Indonesia revealed that participants had a low and inconsistent understanding regarding climate change and its impact on health (Sulistyawati et al., 2018), which is consistent with this study as only $10 \%$ of the respondents had adequate awareness. The result is also similar to the finding of the study conducted on Knowledge on Climate Change and its Impact in Human Health among Health Sciences Students of Pokhara Valley, Nepal where $29.3 \%$ depicts good knowledge (Chalise et al., 2015). 


\section{CONCLUSION}

The study concluded that half of the secondary level students have the inadequate level of awareness on effects of climate change on health in Biratnagar. It is recommended that students' awareness should be increased by involving them in project work activities such as doing researches on topics related to afforestation, reducing use of firewood, considerate use of non-renewable resource of energy, waste management, etc.

\section{ACKNOWLEDGEMENTS}

The authors would like to express gratitude and thanks to Tribhuvan University, Institute of Medicine, Biratnagar Nursing Campus, Biratnagar for providing the opportunity to carry out this research work. We wish to extend heartfelt gratitude to Principal of Jaycee Bal Sadan Secondary School of Biratnagar and all the respondents for their kind cooperation and valuable time.

\section{REFERENCES}

Barimah, P.T., Kwadwo, S.O. \& David O. (2015). Assessment of people's knowledge and perception on climate change: A case study of Asunafo North District, Ghana. International Journal of Innovative Research in Science, Engineering and Technology, 4(1), 18417-18424. https://ijirset.com/upload/2015/ january/ 3_Assessment.pdf

Bello, T. O. (2014). Assessment of secondary school students' awareness of climate change. International Journal of Scientific Research and Education,2(12), 2713-2723.

Caranto, B.F. \& Pitpitunge, A.D. (2015). Students' knowledge on climate change: Implications on interdisciplinary learning. Biology Education and Research in a Changing Planet. Springer, Singapore, 21-30. doi.org/10.1007/978-981-287524-2_3

Carr, P., Buggy, C. J., \& McGlynn, G. (2015, September). Climate change awareness amongst secondary level students' in a Dar es Salaam University College of Education (DUCE) affiliated school in urban Tanzania. In United Nations Sustainable Development Network 3rd Annual International Conference on Sustainable Development Practice, Columbia University, New York, USA, 23-24 September 2015.

Chalise, M., Pathak, G., Parajuli,S., Chalis, A. M., Thakur, P. \& Chauhan, H.S. (2015). Knowledge on climate change and its impact in human health among health sciences students of Pokhara Valley, Nepal. International Journal of Health Sciences \& Research, 6(1), 362-370. https://www.researchgate.net/profile/ Pratap_Thakur/publication/293555921_Knowledge_on_Climate_Change_and_It s_Impact_in_Human_Health_among_Health_Sciences_Students_of_Pokhara_V alley_Nepal/links/56baf57008ae0a6bc955776d/Knowledge-on-Climate-Changeand-Its-Impact-in-Human-Health-among-Health-Sciences-Students-of-PokharaValley-Nepal.pdf

Dhital, S.R., Koirala, M., Dhungel, S.,Mishra, R. K. \& Gulis, G. (2016). Climate change and its impacts on human health in Nepal. Journal of Health Education Research \& Development. 4(2). doi:10.4172/2380-5439.1000174

Kabir, M. I., Rahman, M. B., Smith, W., Lusha, M. A. F., Azim, S. \& Milton, A. H. (2016). Knowledge and perception about climate change and human health: Findings from a baseline survey among vulnerable communities in Bangladesh. BMC Public Health, 16(266). doi.org/10.1186/s12889-016-2930-3 
Majra, J. P. \& Acharya, D. (2009). Protecting health from climate change: Preparedness of medical interns. Indian Journal Community Medicine, 2009(34),317-320. http://www.ijcm.org.in/text.asp?2009/34/4/317/58390

Rahman, M.S., Hossain, M.A., Zaman, M.H. \& Mannan, M. (2018). Awareness on climate change: Perceived physical and psychological impact among the young generation. least developing country's perspective.Interdisciplinary Environmental Review, 1(19), 91-101. https://www.inderscienceonline.com/ doi/abs/10.1504/IER.2018.089783

Rahman, M. S, Mohamad, O. \& Zarim, Z.B.A. (2014). Review of health impacts and perceived awareness of climate change by young citizens. Global Journal of Health Science, 6(4), 196-204. doi: 10.5539/gjhs.v6n4p196

Karami, S., Shobeiri, S.M., \& Jafari, H. (2017). Assessment of knowledge, attitudes, and practices (KAP) towards climate change education (CCE) among lower secondary teachers in Tehran, Iran.International Journal of Climate Change Strategies and Management, 9(3). doi: 10.1108/IJCCSM-04-2016-0043

Sulistyawati, S., Mulasari, S. A., \& Sukesi, T. W. (2018). Assessment of knowledge regarding climate change and health among adolescents in Yogyakarta, Indonesia. Journal of Environmental and Public Health, 2018(9716831). doi.org/10.1155/2018/9716831

Theodora, O.B. (2014). Assessment of secondary school student's awareness of climate change. International Journal of Scientific Research and Education, 2(12), 2713-2723.

https://www.researchgate.net/publication/286920079_Assessment_of_Secondary _School_Students\%27_Awareness_of_Climate_Change

United States Environmental Protection Agency. (2017). Understanding the Connections between Climate Change and Human Health. Washington, DC: Retrieved from https://www.epa.gov/climate-indicators/understanding-connections-betweenclimate-change-and-human-health

World Health Organization. (2018). Climate change and health. Geneva. http://www.who.int/en/news-room/fact-sheets/detail/climate-change-and-health

Yang, L., Liao, W., Liu, C., Zhang, N., Zhong, S., \& Huang, C. (2018). Associations between Knowledge of the Causes and Perceived Impacts of Climate Change: A Cross-Sectional Survey of Medical, Public Health and Nursing Students in Universities in China. International journal of environmental research and public health, 15(12), 2650. https://doi.org/10.3390/ijerph15122650 